\title{
Transfusion Support and Red Cell Alloimmunisation in
}

\section{Thalassemia Patients}

\section{Dibyajyoti $S^{*}$}

Department of Transfusion Medicine, All India Institution of Medical Sciences, India

Editorial

Volume 2 Issue 1

Received Date: May 31, 2018

Published Date: June 06, 2018

DOI: $10.23880 /$ hij-16000123

India Institution of Medical Sciences, Bhubaneswar, Odisha, India, Email:

dib.jit@gmail.com

\section{Editorial}

Thalassemias are the most common mono genetic disease worldwide. It has high frequency extending from the Mediterranean basin through the Middle East (Iran), India and Southeast Asia [1]. In India, the carrier rate of Beta Thalassemia varies from $3-17 \%$ [2]. There is complete or partial defect in synthesis of alpha or beta globin chain synthesis, accordingly named alpha or beta Thalassemia. $\beta$ Thalassemia may be classified in to 4 categories. 1) Thalassemia major, Thalassemia intermedia, Thalassemia minor (trait), silent carrier. Thalassemia major patients usually present early and are transfusion dependent. Patients with $\beta$ Thalassemia trait (Thalassemia minor) have elevated hemoglobin A2 on hemoglobin electrophoresis as well as mild anemia and microcytosis. They do not require red cell transfusion. Patients with $\beta$ Thalassemia intermedia presents late with variable levels of anemia and is of the NonTransfusion-Dependent-Thalassemia (NTDT) phenotype. Due to the severity of their anemia or complications of their disease some patients will go on to chronic transfusions. Thalassemia carriers are asymptomatic \& usually have no hematologic abnormalities.

Main stay of treatment is blood transfusion and iron chelation. Transfusion goal for Thalassemia patients should be between 9 and $10 \mathrm{~g} / \mathrm{dl}$. To achieve this goal we require monthly transfusion in infants and young children, with transfusions every three weeks in adolescent and adult patients. Post transfusion hemoglobin should be $12-13 \mathrm{~g} / \mathrm{dl}$. Splenomegaly can lead to hyper splenism with an increase in blood requirement. If the annual blood requirement is over $200 \mathrm{ml} / \mathrm{kg} /$ year Splenectomy should be considered. Splenectomy usually reduces the annual red cell requirement. Before splenectomy, patients should be fully immunized. Treatment with aspirin following splenectomy can decrease the risk of pulmonary hypertension [3]. Aspirin is not an effective treatment once pulmonary hypertension is established [4].

Leuko reduced products are indicated for all Thalassemia patients, but they don't need irradiated blood products. Radiation damages the red cell membrane and shortens red cell survival. The only indication for irradiation is for patients who are immune suppressed or who will possibly have a progenitor cell transplant [5]. Saline washed Red cells are not required unless the recipient has had a urticarial or other transfusion reaction that could be avoided by washed units. Cytomegalovirus (CMV) infections should be prevented in patients those likely to receive a progenitor cell transplant and women who are pregnant. Leukocytereduced blood products are CMV free and thus should be used to prevent CMV infections.

Transfusion should be by PRBC (packed Red Blood Cell) not be by whole units. Volume of transfusion should be calculated for pediatric patients. A simple method of calculating red cell requirement is: the desired hemoglobin minus the current hemoglobin, multiplying by a "transfusion factor" of 3 /hematocrit of transfused red cells (3/ Hct), and then by the weight of the patient in kilograms:

$($ Hgbd - Hgbc) $(3 /$ Hematocrit $)($ Weight in $\mathrm{Kg})=$ millilitres of red cells to transfuse [6]. 
Red cell units can be "split" by the blood bank to conserve the blood supply. Transfusion in patients with anemia may lead to a mild volume over load that is tolerated by most patients, but it can lead to cardiac overload in older patients or those with cardiomyopathy that requires monitoring [7]. Diuretics should be considered if the transfused volume is greater than $20 \mathrm{ml} / \mathrm{kg}$.

Alloimmunization is defined as an immune response to foreign foreign antigens after exposure to genetically different cells or tissues. It is a common problem in patients getting multiple blood transfusions. Consequences of alloimmunisation are Difficulties obtaining compatible blood, increase frequency of transfusion, acute or delayed hemolytic transfusion reactions and hemolytic disease of the newborn. The factors contributing to alloimmunization are the RBC antigenic difference between the blood donor and the recipient, the recipient's immune status \& the immunomodulatory effect of the allogeneic blood transfusions on the recipient's immune system [8]. The prevalence of alloimmunization ranges from $3.1 \%$ to $37 \%$ in patients of different ethnic origin [9]. In India the prevalence of alloimmunization in multi-transfused patients varies from $3 \%$ to $10 \%[10-12]$.

Alloantibodies are the antibodies produce against the red cell antigens which the recipient lacks. The common antigens causing red cell alloimmunization are: D, E, e, C, c, K, k, Jka, Jk b, Fya, Fy b, S, s, M, N, Le a, and Le b [13]. Phenotyping of these antigens are recommended at minimum. This information will help in investigating when an alloantibody is suspected. Whenever any alloantibody is detected, corresponding antigen-negative blood should be provided to patients. Partially phenotypically matched red cells for Rh (D,C,c,E,e) and Kell antigen significantly decreases incidence of alloimmunization [14]. For Thalassemia patients the age of beginning transfusion influences the rate of alloimmunization. Children beginning transfusion early (<one year of age) having less alloimmunization $(11 \%$ vs. $30 \%$ [15]. For all thalassemic patients it is important to important to detect alloantibodies. Indirect Coombs test, Antibody screening panel ( 2 cell, 3cell, 4 cell panels) \& antibody detection panels (11cell, 16 cell panels) are commonly used to detect alloantibodies. If detected antigen-negative blood should be provided to patients.

In summary it is advisable to perform an extended RBC phenotype (ABO, Rh, Kell, Kidd, Duffy, Lewis, MNS) of all Thalassemic patients before administering first blood transfusion. Antibody screening to be performed regularly to detect culprit alloantibody if present. Proper counselling to all alloantibody positive patients required so that they get antigen negative blood transfusion only. Whenever possible phenotype matched blood (at least $\mathrm{Rh} \&$ Kell) should be administered.

\section{References}

1. Sadeghian $M H$, Keramati MR, Badiei Z, Ravarian M, Ayatollahi H, et al. (2009) Alloimmunization among transfusion dependent thalassemia patients. Asian J Transfus Sci 3(2): 95-98.

2. Agarwal S, Gupta A, Gupta UR, Sarwai S, Phadke S,et al. (2003) Prenatal diagnosis in beta thalassemia: An Indian experience. Fetal Diagn Ther 18(5): 328-332.

3. Shen L, Shen J, Pu J, He B (2011) Aspirin attenuates pulmonary arterial hypertension in rats by reducing plasma 5-hydroxytryptamine levels. Cell Biochem Biophys 61(1): 23-31.

4. Kawut SM, Bagiella E, Lederer DJ, Shimbo D, Horn EM, et al. (2011) Randomized clinical trial of aspirin and simvastatin for pulmonary arterial hypertension: ASA-STAT. Circulation 123(25): 29852993.

5. Rachmilewitz EA, Giardina PJ (2011) How I treat thalassemia. Blood 118(13): 3479-3488.

6. Davies P, Robertson S, Hegde S, Greenwood R, Massey E, et al. (2007) Calculating the required transfusion volume in children. Transfusion 47(2): 212-216.

7. Raj S, Killinger J, Overby P (2013) Blood transfusion in sickle cell disease leading to posterior reversible encephalopathy syndrome (PRES). J Child Neurol 28(10): 1284-1286.

8. Singer ST, Wu V, Mignacca R, Kuypers FA, Morel P, et al. (2000) Alloimmunization and erythrocyte autoimmunization in transfusion-dependent thalassemia patients of predominantly Asian descent. Blood 96(10): 3369-3373.

9. Dhawan HK, Kumawat V, Marwaha N, Sharma RR, Sachde S, et al. (2014) Alloimmunization and autoimmunization in transfusion dependent thalassemia major patients. Study on 319 patients. Asian J Transfus Sci 8(2): 84-88. 
10. Lamba DS, Kaur R, Basu S (2013) Clinically Significant Minor Blood Group Antigens amongst North Indian Donor Population. Adv Hematol 2013: 215454.

11. Shukla JS, Chaudhary RK (1999) Red cell alloimmunization in multi-transfused chronic renal failure patients undergoing hemodialysis. Indian J Pathol Microbiol 42(3): 299-302.

12. Sood R, Makroo RN, Riana V, Rosamma NL (2013) Detection of alloimmunization to ensure safer transfusion practice. Asian J Transfus Sci 7(2): 135139.

13. Lasalle-Williams M, Nuss R, Le T, Cole L, Hassell K, et al. (2011) Extended red blood cell antigen matching for transfusions in sickle cell disease: are view of a 14-year experience from a single center (CME). Transfusion 51(8): 1732-1739.

14. Castro O, Sandler SG, Houston Yu P, Rana S (2002) Predicting the effect of transfusing only phenotypematched RBCs to patients with sickle cell disease: theoretical and practical implications. Transfusion 42(6): 684-690.

15. Vichinsky E, Neumayr L, Trimble S, Giardina PJ, Cohen AR, et al. (2014) Transfusion complications in thalassemia patients: a report from the Centers for Disease Control and Prevention (CME). Transfusion 54(4): 972-981. 